\title{
HISTORICAL ALLOTMENT GARDENS IN WROCŁAW - THE NEED TO PROTECTION
}

\author{
Wanda KONONOWICZ ${ }^{1}$, Katarzyna GRYNIEWICZ-BALIŃSKA ${ }^{2}$ \\ ${ }^{1}$ University of Zielona Gora, Zielona Góra, Poland \\ ${ }^{2}$ Technical University of Wroclaw, Wrocław, Poland
}

\begin{abstract}
Since about the mid-nineteenth century, together with the changing socio-economic situation, different types of allotments appeared in Wrocław. Initially, they were rented gardens, gardens for the poor or for factory workers. At the beginning of the twentieth century, school gardens and the so called Schreber gardens with a large common square were set up as part of Dr. Schreber's educational health program. In 1914-1918, "war" vegetable gardens were commonly cultivated. In the 1920s allotment gardens began to be systematically introduced to the city plan as permanent, purposefully designed elements of urban greenery. They were often designed together with urban parks, or so called "Folk Parks" of a recreational and sport character. In the 1930s, during the economic crisis, allotments with garden houses were adapted for the unemployed and the homeless to live in. Wrocław allotment gardens have undeniable historical, social, recreational, economic and compositional value. These gardens are a cultural heritage that should be protected. In Western Europe we are witnessing a renaissance of the idea of allotments, while in Poland - a tendency to eliminate them from urban landscapes.
\end{abstract}

Keywords: urban greenery, allotments, typology, protection of cultural heritage, Wrocław, the first half of the twentieth century.

\footnotetext{
${ }^{1}$ Corresponding author: University of Zielona Gora, Faculty of Civil Engineering Architecture and Environmental Engineering, Szafrana st 1, 65-516 Zielona Góra, Poland, e-mail: wandakononowicz@wp.pl

${ }^{2}$ Corresponding author: Technical University of Wroclaw, Faculty of Architecture, Prusa st 53/55, 50-377 Wrocław, Poland, e-mail: katarzyna.gryniewicz@ gmail.com
} 


\section{INTRODUCTION}

The history of Wrocław allotment gardens proves that they were a very important aspect of everyday life: the financial support, the source of healthy food, they provided contacts with the nature, and the place for family meetings, recreation and education, a place of a pro-health character. We should protect the historical allotments and manage them wisely due to the respect for the cultural heritage and also with regard to the role they have still been playing in the social life [2].

\section{HISTORICAL VALUE OF ALLOTMENTS}

Allotment gardening in Germany has a long and rich history dating back to the 1820s. It was then when allotment gardens for poor artisans and workers without a permanent job were first founded in Kiel. In Wrocław, the first such gardens appeared in 1840 . With time, rented gardens, despite their temporary character, became very popular with poor working-class families, living in rental homes. They could enjoy the sense of communion with nature and to have the possibility to grow vegetables.

The so called Schreber gardens (Schrebergärten) started to be set up in Germany since the 1870s, and in Wrocław - from the beginning of the twentieth century. The gardens were inspired by the ideas of Dr. Daniel Schreber (18081861) - an orthopaedic surgeon and scientist from Leipzig, who - worried about children's health - promoted the creation of urban playgrounds. Schreber gardens brought new quality to allotment gardening as their assumptions were carefully designed and had various functions: economic, educational, health, cultural and recreational. In addition to growing vegetables, fruit and flowers, the gardens provided a place where outdoor activities for children such as various plays, performances and competitions were organized in the purposefully designed spacious common square. Schreber gardens were founded in a planned manner and thy were permanent in nature.

The first Schreber garden in Wrocław, mentioned in the literature as a model example for a landscape garden, was built in 1901 in the area of the former Pond Fields (Pola Stawowe), in the area of today's Gliniana Street (area of 1.2 ha) (Fig. 1, Fig. 2). Subsequent gardens were founded at Odrzańskie and Piaskowe suburbs (3.5 ha) in 1906 (Fig. 3), and the next - in 1907 in Popowice (3 ha) and in the same year - Karłowice (2.8 ha). A total of a dozen of Schreber gardens were established before World War II.

A characteristic element of the arrangement of the gardens was, according to Schreber's idea, a common playground (Fig.2). Also the gardens were provided 
with a general-use building with toilets and a room for tools. It was mainly located on the entrance axis. Sometimes a gazebo was designed to provide shade or shelter from the rain.

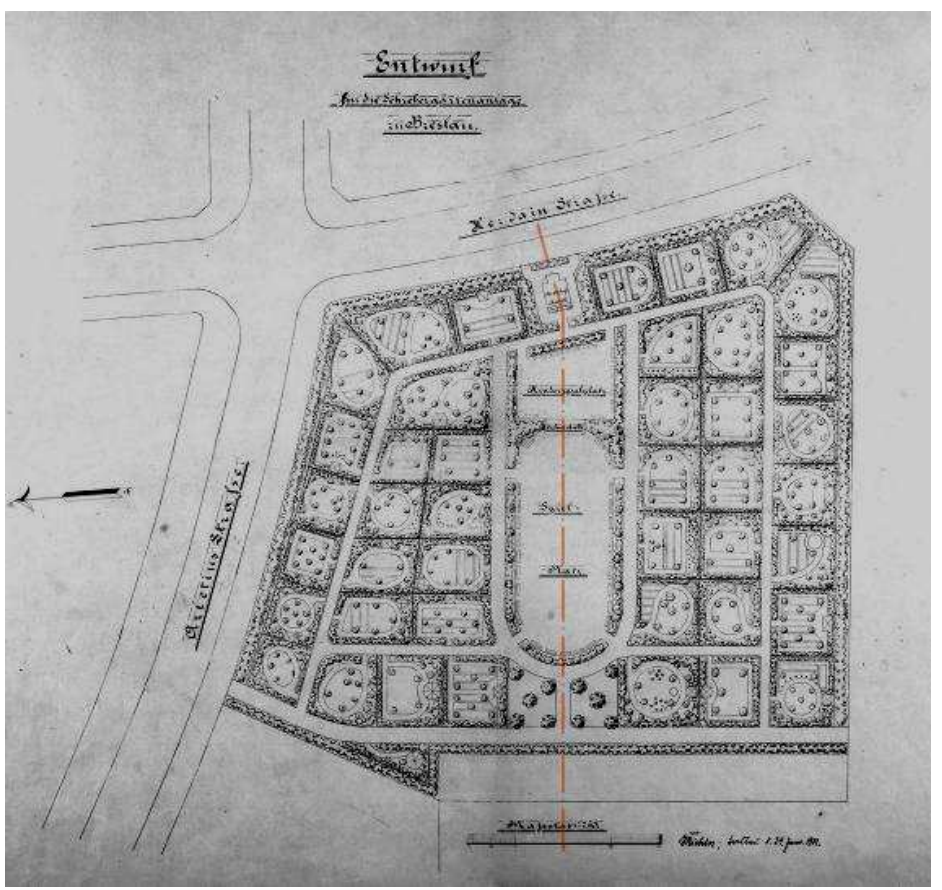

Fig. 1. Schreber gardens on Pola Stawowe. Designed by H. Richter, 1901. Source: Architectural Archive of the City of Wrocław

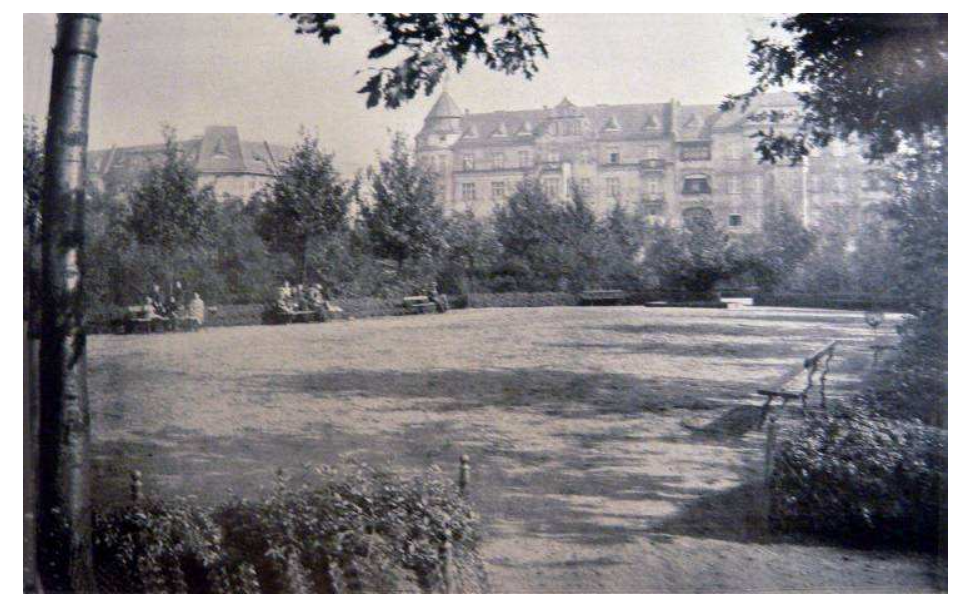

Fig. 2. Playground in the gardens in Pola Stawowe (Pond Fields). Phot. 1912 [1]. 
At the end of the nineteenth century, factory owners began set up workers' gardens (Arbeitergärten, Fabriksgärten, Eisenbahngärten), as a useful way to provide space for their employees to spend their free time, to the benefit of their health and family relationships. In Wrocław, first such gardens were founded in 1908 by Meinecke's factory of water meters in Karłowice, and another - in 1913 - by Linke-Hoffman-Werke factory in Grabiszyn.

At the end of the first decade of the twentieth century, the Red Cross started to set up workers' gardens, with a health and social program, intended primarily for the sick during recuperation.

During the First World War, allotments were mainly used as a food source, where potatoes and sugar beets, as well as berry bushes and herbs were grown. In Wrocław, war vegetable gardens were set up at the southern outskirts of the city, and in Karłowice, Kozanów, Zalesie and Swojczyce. They were of a temporary nature and were dominated by utilitarian functions.

After the First World War the developing organizations associating allotment gardens began to re-promote and include in their programs care for children and young people, called "Schreber youth" (Schreberjugend).

In 1912, in Gdansk, at the first congress of the German allotment gardening, the participants postulated setting up allotment gardens, of a permanent nature, in cities (Dauerkleingärten, Dauergärten) [1]. After the First World War, this postulate was realized due to social demand and with the support of urban planners. In 1925, Leberecht Migge, a landscape architect, carried out a survey on permanent allotments. All twenty urban planners who answered this survey supported the plans, acknowledging the gardens as an important part of a city.

In Wrocław of the 1920s, allotments began to be systemically introduced into the plan for the city. This was based on a gradually elaborated laws and urban planning documents: plan for surface distribution (Flächenaufteilungsplan) and the general plan of land development (Generalbebauungsplan) which included large complexes of allotments near sports sites, playgrounds and in the neighborhood of parks [4]. The status of permament gardens was granted to the existing Schreber gradens in the first place. In the case of Wrocław, this change can be observed by comparing, for example, zonal plans from 1912 and the plans for green areas from 1926. Since 1928, after the national Congress of gardeners in Wrocław, new permanent gardens were planned and founded. In the city plan of 1934, 11 gardens were planned. They were located uniformly on the circumference of the ring around the centre, according to the guidelines of the Association of German Allotment Gardens. In the scale of a big city, the permanent allotments played an important respiration role. They were often connected with other urban green areas: parks, playgrounds, squares, sports 
facilities and bathing waters (Fig. 3), and sometimes they were vast areas of entertainment and recreation, the so-called Folk Parks [2].

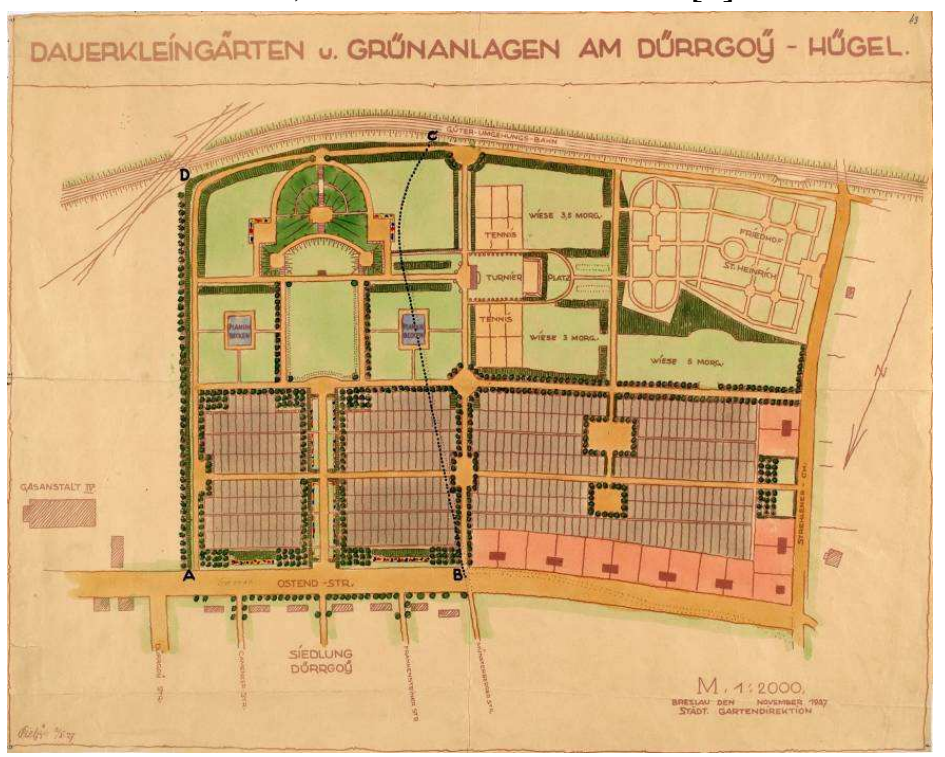

Fig. 3. Unrealized plan of the park with allotments in Tarnogaj, 1927. Source: Architectural Archive of the City of Wrocław

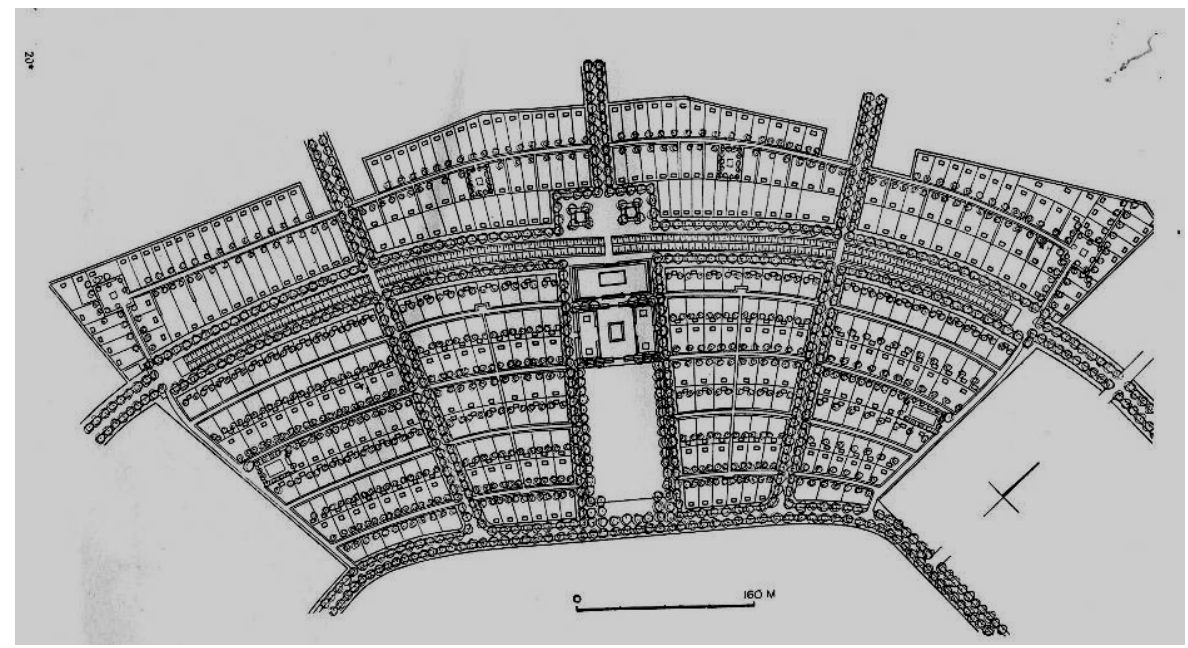

Fig. 4. Allotment gardens in Kowale of approx. 1929. Drawing elaborated by A. Ptaszycka, 1956. [7, p. 307]

The permanent gardens were the large-scale Schreber gardens with a richer functional and spatial program (e.g. several playgrounds), based on a regular, 
axisymmetric plan. The regular outline plan often was based on geometric figures. The gardens usually consisted of two parts - public places (squares and greenery) and intimate places (garden plots and a playgrounds). In Wrocław, the largest permanent allotment garden was founded in the late $20 \mathrm{~s}$ and $30 \mathrm{~s}$ in Kowale, where, on the plan of an unfolded fan of approx. 25 hectares, more than 400 allotments were planned (Fig. 4).

In times of crises, allotment gardens were a great economic help for the homeless and the unemployed. In 1919, the President of Wrocław Regierungsbezirk issued one of the first in Germany regulation allowing installation of residential sheds, which aimed at the alleviation of an acute housing crisis after the First World War. In response to the global crisis of the 1920 s, president of the Reich announced a regulation allowing the construction of the so-called crisis housing estates, where one of the forms were settlements of residential sheds, which were often allotment gardens of permanent nature. Several such settlements were set up in Wrocław, some of which have preserved to this day, including in Książ Mały (1934), Maślice Małe, (1932), Maślice Wielkie (1935), and in Osobowice (1933).

Allotment gardening had an essential social value, which was reflected in the contemporary legal acts and the acceptance of the executive branch at the state, Regierungsbezirk and city levels. The Act on allotments and small leased plots of 1919 [3] was introduced to facilitate and protect the allotment owners in terms of the leased land. In every town and county a special office for allotment gardens was established. The constitution of the Weimar Republic of 1919 obliged municipalities to acquire land for the purpose of allotment gardening. In 1924, the so-called Heimstättengärten Regulation was introduced establishing areas for allotment gardens in close proximity to city centres.

The long and varied history of allotment gardening as well as its tangible artefacts in the form of preserved gardens are important cultural heritage. As such, they deserve protection and respect, and not - neglect and removal from the urban landscape, which seems now the dominant trend. Historical allotment gardens, as well as historic architecture and urban systems are part of an original plan of the city and the urban landscape.

In Wrocław, most of the historical gardens survived to this day, although their original shape have changed (no historical huts preserved, and sometimes the original layout of the allotments was changed). Historical gardens are often heavily neglected and require comprehensive revaluation actions, which should aimed at maximum possible preservation of their historical value and customizing their function to modern conditions. 


\section{SOCIAL, RECREATIONAL AND ECONOMIC OF THE TODAY'S GARDENS}

Allotment gardening is still of a crucial social importance. It is estimated that approximately 4 million people take advantage of allotment gardening (including the owners and their families). The owners themselves are much older than their colleagues from before the war: the majority are pensioners, while in the 1930s in Germany, most were professionally active: workers, clerks, craftsmen.

Currently in Poland neither the central government nor local authorities are not interested in supporting allotment gardening. In cities there is a tendency to liquidate allotments and to replace them with residential buildings and buildings for commercial purposes. The interst of indebted cities which want to cash the real estate, responds to the investors' attempts to favourably invest their money in a few years' perspective. In 2006, in Wroclaw, as much as $75 \%$ of the allotments are planned for liquidation. Although the recently passed law on allotments [8] provides some level of their protection, but there are still new ways of discouraging garden owners to cultivate their allotments.

Recently, the legality of a masonry garden gazebo is questioned. Construction supervision, supported by the judgement of the Supreme Administrative Court ruled that a gazebo is a building of lightweight construction, designed to protect against sun and rain. There are approximately 900 thousand gazebos in allotment gardens in Poland, but most of them do not correspond to the definition given, and therefore constitute unauthorized construction and should be dismantled.

This applies in particular to historical, preserved residential gazebos in Wrocław. This naive definition would not be met by the bricked arbor houses (Wohnlauben), designed in the 1930s, by Heinrich KNIPPING, the director of the City Planning Office; gazebos designed in the same period by the office for allotments or Ernst May's prototype residential gazebo built in the 1920 on the outskirts of Złotniki in Wrocław. It is worth noting that these projects were to serve as models for repeated realization in allotments. At the moment, there are opinions as to gazebos built nearly 100 years ago claiming that the name is misused and that in fact they should not be called gazebos.

It should be remembered that the liquidation of allotments can disrupt development of the city [6]: it can help to lower the quality of the living environment, the depletion of recreational areas in the vicinity of residential areas, reducing opportunities for active recreation and healthy lifestyles, reducing the social quality of the city. 
Social, economic and recreational function of allotments are still valid, as can be seen, even visiting Berlin, beautiful maintained and extensive gardens. In developed countries, initiatives such as vertical gardens and urban farms are trying to provide local residents with contacts with nature or access to their own-produced, healthy food. In the UK, organization Allotments Regeneration Initiative operated for 10 years, until 2012. It promoted the restoration of neglected allotments and the formation of new gardens, and in 2011 the Prince of Wales took over the patronage of the National Allotment Association. Scientific research confirms that even a slight green areas in the city center can provide a clear reduction of air temperature and contribute to the reduction of the effect of an urban heat island [5].

The allotment gardens, preserved in Wroclaw, are not only of the historical value, but they can still fulfill important social, recreation, health and economic functions.

Some gardens present special historical and aesthetic values and their former nature should be restored. For the first Schreber garden, on Pola Stawowe, the common playgrounds (for recreation) should be restored (in the place of the former square, there are lots now). In the largest permanent garden in Kowale and in the former gazebo residential area, Księż Mały, it would be necessary to introduce the historical standardization of gazebos, which would probably involve the replacement of the existing buildings with model gazebos. Currently, in addition to extremely complex masonry garden houses, there are hundred-year-old wooden, practically devastated gazebos, and their plots are often deprived of fences. In the gardens in Kowale, it would be advisable to redevelop the neglected, open to the public, square for common recreation. The redevelopment should be supplemented with the recomposition of greenery and the exchange of small architecture. In addition, the recomposition of greenery should also be carried out along the walking routes.

Many of the historical allotment gardens should be opened, i.e. the walking paths should be made available to the public, and the gardens should be associated with other urban green areas (e.g. Historic permanent gardens in Tarnogaj and Osobowice). Some of the gardens have been of such a nature since their beginnings (i.e. permanent gardens in Sepolno and Kowale).

But the public access does not always make sense, e.g. in the case of small enclaves, located among residential areas or away from other recreational areas such as the Schreber gardens in Pola Stawowe and Sepolno, (the first one, much smaller, planned together with a housing estate).

Historical allotment gardens, especially those close to the center, after the revitalization work, should be given special protection, perhaps even a conservation protection. 


\section{CONCLUSIONS}

Allotment gardening have been important in the life and functioning of Wrocław's residents. Their designs were elaborated by municipal planners, and the allotment gardening was under the care of an office for the allotment gardens, and their social significance was appreciated by the local authorities. Although a variety of functions of the gardens are still valid - the attitude towards them presented by urban planners, city authorities and legislators is now radically different. Allotments are not obsolete, but perhaps some of them require recovery. We should protect historical gardens and support the development of the newly formed ones. The incentive for this can be found in the program supported by the United Nations Agenda 21, in which local governments are committed to ensuring residents well-designed allotments available for all social groups.

\section{REFERENCES}

1. Familiengärten und andere Kleingartenbestrebungen in ihrer Bedeutung für Stadt und Land. Vorbericht und Verhandungen der 6. Konferenz der Zentralstelle fur Volkswohlfahrt in Danzig vom 18 Juni 1912, Berlin, Carl Hehmanns Verlag 1913.

2. Gryniewicz-Balińska K.: Rozwój ogrodów działkowych we Wrocławiu od końca XIX w. do II wojny światowej, Wrocław 2013, praca doktorska napisana pod kierunkiem prof. dr hab. arch. Wandy Kononowicz

3. Kleingarten- und Kleinpachtlandordnung ( $\mathrm{nr}$ 6977), Reichs-Gesetzblatt, 150 (1919), 1371-1374.

4. Kononowicz W.: Wroctaw. Kierunki rozwoju urbanistycznego w okresie międzywojennym, Wrocław, Oficyna Wydawnicza Politechniki Wrocławskiej 1997.

5. Oliveira S., Andrade H., Vaz T.: The cooling effect of green spaces as a contribution to the mitigation of urban heat: a case study in Lisbon, Building and Environment, 46 (2011), 2186-2194.

6. Pawlikowska-Piechotka A.: Tradycja ogrodów dziatkowych $w$ Polsce, Gdynia, Novae Res - Wydawnictwo Innowacyjne 2010.

7. Maleczyński K., Morelowski M., Ptaszycka A.: Wroctaw. Rozwój urbanistyczny, Warszawa, 1956.

8. Ustawa z dnia 13 grudnia 2013 r. o rodzinnych ogródkach działkowych, Dz. U. z 2014 r., poz. 40. 


\section{HISTORYCZNE OGRODY DZIAŁKOWE WE WROCŁAWIU - POTRZEBA OCHRONY}

\section{Streszczenie}

Od około połowy XIX wieku, wraz ze zmianami sytuacji społeczno-gospodarczej, pojawiały się we Wrocławiu różne typy ogródków działkowych. Początkowo były to ogródki: dla biednych, czynszowe i przyzakładowe. $\mathrm{Z}$ początkiem $\mathrm{XX}$ w., w ramach realizacji programu wychowawczo - zdrowotnego dra Schrebera, zakładano ogrody szreberowskie z dużym wspólnym placem, jak również ogródki szkolne. W latach 19141918 rozpowszechniły się wojenne ogródki warzywne. W 20. latach XX w. zaczęto systemowo wprowadzać ogrody działkowe do planu miasta jako stałe, świadomie projektowane elementy miejskiej zieleni. Często projektowano je w powiązaniu z parkami miejskimi, bądź tzw. Parkami Ludowymi o charakterze rekreacyjno sportowym. W latach 30. XX w., w dobie kryzysu gospodarczego, zakładano tzw. osiedla działkowe $\mathrm{z}$ altanami mieszkalnymi dla bezrobotnych i bezdomnych. Wrocławskie ogrody działkowe maja niezaprzeczalne walory historyczne, społeczne, rekreacyjne i gospodarcze oraz kompozycyjne. Założenia te stanowią dziedzictwo kulturowe które powinno podlegać ochronie. W krajach Europy Zachodniej obserwujemy renesans idei ogrodów działkowych, natomiast w Polsce tendencję do rugowania ich z pejzażu miasta.

Słowa kluczowe: zieleń miejska, ogrody działkowe, typologia, ochrona dziedzictwa kulturowego, Wrocław, pierwsza połowa XX wieku.

Editor received the manuscript: 15.01 .2015 